Article

\title{
Is Religion Coming Back as a Source for Antisemitic Views?
}

\author{
Gunther Jikeli \\ College of Arts and Sciences, Indiana University, Bloomington, IN 47405, USA; gjikeli@indiana.edu
}

Received: 20 February 2020; Accepted: 13 March 2020; Published: 20 May 2020

\begin{abstract}
The most violent American and European antisemites in the 21st century, including not only Jihadists but also white (and black) supremacist terrorist, made some reference to religion in their hatred of Jews. This is surprising. Religious antisemitism is often seen as a relic of the past. It is more associated with pre-modern societies where the role of religion was central to the social and political order. However, at the end of the 19th century, animosity against Judaism gave way to nationalistic and racist motives. People such as Wilhelm Marr called themselves antisemites to distinguish themselves from those who despised Jews for religious reasons. Since then, antisemitism has gone through many mutations. However, today, it is not only the actions of extremely violent antisemites who might be an indication that religious antisemitism has come back in new forms. Some churches have been accused of disseminating antisemitic arguments related to ideas of replacement theology in modernized forms and applied to the Jewish State. Others, from the populist nationalist right, seem to use Christianity as an identity marker and thus exclude Jews (and Muslims) from the nation. Do religious motifs play a significant role in the resurgence of antisemitism in the 21st century?
\end{abstract}

Keywords: religious antisemitism; supersessionism; replacement theory; Bowers; Poway; Pittsburgh; Jersey; Black Hebrew Israelites

Religious antisemitism is often seen as a relic of the past. It is more associated with pre-modern societies where the role of religion was central to the social and political order and where Jewish beliefs and rituals were seen as a problem. Scholars often refer to religious antisemitism as anti-Judaism rather than antisemitism. The latter term was coined only at the end of the 19th century by self-identified antisemites such as Wilhelm Marr. His 1879 pamphlet "Victory of Jewry Over Germanism. Views from a Nonreligious Point of View" is revealing in that shift. Marr called himself an antisemite but denounced "the religious side of this hatred", which he considered "idiotic" (Marr 1879, p. 7, author's translation). He explicitly rejected religious accusations, such as blaming Jews for the crucifixion of Jesus. He also said he did not hate Jews. His approach was supposedly rational. He felt resignation in the face of the allegedly powerful and dominating Jewish people who oppressed the Germans.

In a secularized society, religion and feelings of hate were not legitimate arguments anymore to justify polemics and discrimination against Jews. Marr and others proudly called themselves antisemites, but they did not want to be confused with religiously motivated Jew-haters. Now, more than 100 years later, the question of whether religious forms of Jew-hatred are coming back seems anachronistic.

Throughout the history of antisemitism, the most powerful accusations against Jews have been related to the dominant set of ideals in society. In societies where the ideal was to please God and where justifications of socio-political order were dominated by religion, the most powerful accusations were made in the name of God. Jews were accused not only of rejecting the "true message of God" (which is evidently true for those who do not convert), but also of working against God. Popular accusations against Jews in Christian societies have been accusations of being responsible for the 
betrayal and killing of Jesus Christ; that is, they have been accused of murdering God. Jews have also been accused of the desecration of Christian rituals and of killing Christian children for their own rituals, the so-called blood libel. Anti-Judaism was widespread to the point that it worked even without Jews. There is a long tradition in Christian societies of accusing adversaries of being Jews or being like Jews because they do not share the beliefs deemed as the truth (Nirenberg 2013). In Islamic societies, popular accusations against Jews have included the claim that Jews have abandoned practicing the true religion and have falsified holy scripture, that they are Muslims' enemies, and that they cannot be trusted. $^{1}$

However, in almost all parts of the world, societies are now organized in nation states. Except for a few theocracies, religious justifications of political order have been replaced by worldviews that place the nation at the center of ideals. The shared dogmas in society have ceased to be religious norms, and morals have been secularized. In this new configuration of nation states, the most powerful accusations against Jews have been made in the name of the nation. Jews are not accused of undermining or trying to kill God, but they are accused of degrading or destroying the nation, or of being disloyal to the nation. The Dreyfus affair in France at the end of the 19th century is the most infamous case in point. Captain Alfred Dreyfus, of Jewish origin, was falsely accused of treason. The ensuing trials and public debates were marred by antisemitic tropes of alleged Jewish disloyalty.

Where the concept of the nation revolves around ethnicity or race, accusations against Jews get a racial spin. Wilhelm Marr and other German antisemites of the 19th century depicted their race being dominated and vanquished by the Jews. The Nazis pushed this racist and conspiratorialist form of antisemitism to the extreme, even if the Nazi antisemitism also drew on non-racist forms of Jew-hatred. Religious justifications had been pushed to the margins in most nation states by the beginning of the 20th century even if they still played an indirect role, providing a cultural code of anti-Jewish sentiments (Volkov 1978).

The defeat of Nazism and the horrors of the Holocaust that became public knowledge after the Second World War have delegitimized racist and nationalistic forms of antisemitism. Today, religious, nationalistic, and racist arguments for Jew-hatred are largely discredited. That does not mean, however, that anti-Jewish sentiments have vanished into thin air, but they must be expressed and justified differently—at least in the public sphere.

Since the Second World War, racism and nationalism in general have been in decline, at least until recently. In the 1990s, some scholars even predicted the end of the nation state and the expansion of international human rights law and norms (Hobsbawm 1990; Ohmae 1995; Sassen 1996). This seems to have been premature (Smith 1995, 2000), but international human rights and the idea of post-nationalism certainly still have appeal. In 2015, Canada's prime minister, Justin Trudeau, for example, declared Canada to be "the first post-national state" (Lawson 2015).

The era of human rights and post-nationalism might be more of an aspiration rather than reality in many places, but these ideals also have an impact on how people voice antisemitic feelings in socially acceptable terms. One possible avenue is to focus on the Jewish State instead of Jews. Israel is often accused of everything that is in disfavor today: racism, colonialism, and nationalism, an accusation that in itself is not necessarily antisemitic. ${ }^{2}$ However, the demonization of Israel as a Nazi-like country, the accusation against Israel of the most heinous crimes against humanity-and by proxy against the Jewish colleagues, neighbors, and classmates who are suspected of supporting the Jewish State-might

1 Similar to accusations against Jews in Christianity, anti-Jewish accusations have been made with some reference to religion and sacred texts, and parts of the Qu'ran and the Hadith strongly suggest anti-Jewish views (Bostom 2008). However, different interpretations are possible (Fatah 2010).

2 The differences and similarities between antisemitism and anti-Zionism have been at the center of scholarly debates for decades, see for example the edited volume by Alvin Rosenfeld (Rosenfeld 2019). One of the most outstanding reflections on the issue has been written by British philosopher Bernard Harrison (Harrison 2013). 
be an indication that, after the Second World War, "respectable antisemitism" is often voiced in the form of anti-Zionism and anti-Israelism (Améry 1969; Gallner 2016).

Be that as it may, this short abstract of the history of antisemitic rationales gives no reason to believe that religious antisemitism should make a comeback. However, still, religion is used to justify hatred against Jews in the 21st century and perhaps not only as a relic, but increasingly so.

The most violent American and European antisemites in the 21st century, at least all of those who murdered Jews for being Jewish, made some reference to religion in their hatred of Jews. Many explicitly justified their action in religious terms. This is true not only for all 17 antisemitic murderers of Jews in Europe in the first 18 years of 21st century, who all made some reference to Islamist ideology, but also for the perpetrator of the most violent antisemitic act in the history of the United States to date, the shooting at the Tree of Life synagogue in Pittsburgh, in October 2018, that left 11 Jews dead, referring to them as "the children of Satan". The shooter claimed John, verse 8:44, from the New Testament of the Christian Bible, as the source. The terrorist put this prominently into the self-description of his social media account on Gab, where he announced the acts shortly before he went on a killing spree. The antisemitic perpetrator did have a strong white supremacist worldview, but the religious dimension in his demonization of Jews was also prominent. The shooter at the Poway synagogue in California six months later, on 27 April 2019, was even more explicit. He justified the killing of Jews in a "manifesto", published online in the form of an open letter quoting Bible verses that had been used for centuries to justify hatred against Jews, including the verse that the Pittsburgh terrorist used. Interestingly, he combined white supremacist ideology, seeing the white and European "race" existentially threatened by "international Jewry", with strong Christian beliefs and Christian antisemitic tropes, such as the blood libel and deicide. Do these old tropes of religious anti-Judaism factor into the current ideology of white supremacists? This is surprising because many of the traditions and influential thinkers of the extreme right and the alt-right denounce Christianity (partly because of its Jewish origins), as Mark Weitzman shows in his paper (https://www.mdpi.com/2077-1444/11/5/250) in this Special Issue on the influence of Mircea Eliade, a well-known scholar of religions, on the far political right. Is there an anti-Christian and also a violent Christian current of white supremacists?

The perpetrators of the second most violent attack against Jews in the United States in the 21st century also seemed to be motivated in part by religious beliefs. David Anderson and Francine Graham killed three Jews in a kosher grocery store in Jersey City, New Jersey, 10 December 2019, after killing a police officer. They both showed sympathy to the Black Hebrew Israelites, a group of antisemitic sects that believe that they are the true descendants of the ancient Israelites and that non-black Jews are imposters, a view that Anderson allegedly expressed on social media. The more radical Black Hebrew Israelites sects believe that Jews deserve only death or slavery (Southern Poverty Law Center 2008). In Monsey, NY, on 28 December 2019, another attacker who had expressed sympathy for the Black Hebrew Israelites attacked a Hanukkah celebration at the home of a Rabbi. He stabbed and injured five people with his machete. The links of violent antisemitic perpetrators to Black Hebrew Israelites' ideology is another indicator that religious motivations might be a driving force for some of the most radical antisemites today.

However, it is not only the actions of extremely violent antisemites that might be an indication that religious antisemitism has come back in new forms. Some churches have been accused of disseminating antisemitic arguments related to ideas of replacement theology that were prominent in early Christianity. The small, conservative Orthodox Presbyterian Church with about 30,000 members is one of them, as well as the large and relatively progressive Presbyterian Church (USA) with about 1.7 million members.

Has replacement theology or supersessionism gained new relevance today? Replacement theology is the belief that the Church has superseded the Jewish people. "In other words, the nation of Israel, as it existed as the people of God in the Old Testament is no more. [ ... ] We who trust in Christ are now the nation of Israel!", as expressed by a minister on the Orthodox Presbyterian Church's 
website. ${ }^{3}$ Replacement theology was the most common response for centuries in Christianity to the theological challenge that the Hebrew Bible or the Old Testament clearly refers to a covenant that God has made with the nation of Israel. The idea that "the nation of Israel is no more" delegitimizes Judaism and often had lethal consequences in pre-modern Christian societies. In secular societies, replacement theology is still offensive to Jews and presents a serious obstacle for Jewish-Christian dialogue. However, it cannot be used to justify institutionalized discrimination as it was in the Middle Ages. Moreover, after the Holocaust, most churches have reexamined some of their teachings that had led to anti-Jewish sentiments. The Catholic Church radically changed its doctrines towards Jews following the Second Vatican Council (1962-1965). Its "Declaration on the Relation of the Church to Non-Christian Religions" referred positively to the covenant between the Jewish people and God, and it declared that "the Jews should not be presented as rejected or accursed by God", which had often been the result of replacement theology. Pope John Paul II called Jews the "people of God of the Old Covenant, which has never been revoked by God". ${ }^{4}$ Catholics still believe in the New Covenant with God that supersedes the Old Covenant, but the New Covenant is not seen as replacing the Old Covenant. Protestant views on the covenant between God and the nation of Israel vary, but there have also been attempts to get away from supersessionism. This seems to be less the case with the Presbyterian Churches and with the Orthodox Presbyterian Church, in particular.

However, replacement theology, which has become mostly a question of theology and Christian-Jewish dialogue (or an obstacle to it), can gain new political relevance when applied to today's State of Israel. The idea that the Covenant between God and the Jewish people has ceased to exist and that "the nation of Israel is no more" can lead to political views that are fundamentally hostile to the State of Israel today. Cary Nelson (https://www.mdpi.com/2077-1444/10/6/396) looks at debates within the Presbyterian Church (USA) on the Israeli-Palestinian conflict. He shows that there are competing narratives, but the question of the status of the divine covenant with the Jewish people plays an important role, often in twisted ways. The (false) accusation that Zionists see the State of Israel as the fulfillment of the divine covenant is used to delegitimize Israel. This kind of narrative is nurtured by Palestinian liberation theology. Giovanni Matteo Quer (https://www.mdpi.com/2077-1444/10/8/487) takes a closer look at three of its main proponents, Geries Sa'ed Khoury, Naim Stifan Ateek, and Mitri Raheb. Quer demonstrates that Zionism and Israel are demonized in political and increasingly in religious terms by Palestinian Christian theologians. The arguments resemble, at times, classical antisemitic stereotypes of Judaism from the (Christian) Middle Ages, such as accusations of a sterile and legalistic religion or its supposedly narrow particularistic interests as opposed to a universalistic Christian approach. In the tradition of Augustine of Hippo, Jews should "not be slayed", but they should be scattered and relegated to the role of a disempowered minority. Notions of Zionism and Judaism get conflated in theological arguments against the legitimacy of a Jewish State. The portrayal of Israel as a violation of Christian teachings and as a false interpretation of the Jewish Bible is attractive to Christians who look for justifications of anti-Jewish sentiments in the form of anti-Zionism. But only few churches share this kind of rhetoric, and their theology might be determined more by their political views than the other way around.

Additionally, there are some radical, notoriously antisemitic preachers who gained prominence on either TV or radio shows or on social media. In the United States, Rick Wiles, a conservative preacher and founder of TruNews, is a case in point. In November 2019, he said on his show, "That's the way the Jews work. They are deceivers. They plot. They lie. They do whatever they have to do to accomplish their political agenda. This 'impeach Trump' movement is part of a Jew coup, and the American people better wake up to it fast." (Wiles 2019). However, his rationale seems to be rooted in conspiracy fantasies rather than in his interpretation of religion. Another radical preacher in the

3 Website of the Orthodox Presbyterian Church. Not dated. "Question and Answer. The OPC and national Israel." https://opc.org/qa.html?question_id=466 (accessed on 27 November 2019).

4 Author's translation from German transcript of the speech (Sekretariat der Deutschen Bischofskonferenz n.d., p. 102). 
United States, Louis Farrakhan, leader of the Nation of Islam, includes more references to religion in his rhetoric but is still very much engaged in conspiracy fantasies. He has alleged that the Jewish people were responsible for the slave trade and that they conspire to control the media, Hollywood, and the government. Yet, Farrakhan also refers to the "Satanic Jews", and he denies the legitimacy of Judaism, claiming that it is a "deceptive lie" and a "theological error". Interestingly, this Muslim minister refers to Christian scripture for some of his rants against the "Satanic Jews".

Surveys show that Christian extremists are identified as major groups of perpetrators in some countries. A 2018 survey revealed that $34 \%$ of Jewish respondents in Poland who had become victims of antisemitic acts said that the perpetrator was a Christian extremist. In Hungary, this percentage was 18\% (European Union Agency for Fundamental Rights 2018). In both countries, "Christian extremists" were named as the second largest group of ethnic, political, or religious groups of alleged perpetrators. The largest group of alleged perpetrators in Hungary was the political right.

However, attitude survey data does not seem sufficient enough to determine if there is a rising trend in religious antisemitism. Ildikó Barna and András Kovács (https://www.mdpi.com/2077-1444/10/9/527) look at surveys in Hungary from 2011 and 2017. They found a slight increase in religious antisemitism as well as of secular antisemitism. However, more interestingly, in 2017, it was not personal religiosity anymore that was a significant factor but religion serving as a cultural identity marker. Barna and Kovács relate this to the rebirth of the "Christian-national" idea in Hungary. Being Christian becomes a cultural-political identity marker of the national-conservative camp where antisemitism is more widespread than in other segments of society. Is this a trend also in other countries? Might it even be a factor-in radicalized form-for the aforementioned Christian white nationalist murderers in the U.S.?

What does Islamic religious antisemitism look like? Surveys show that a solid majority in many predominantly Muslim countries affirm antisemitic statements. However, a closer look at the survey data casts some doubt on whether Islamic beliefs are the only, or even the main, motivating factor for this. It seems that other factors, such as national politics, anti-Israelism, or Arab nationalism, are also at play. In 2009, between $95 \%$ and $98 \%$ of the population in Egypt, Jordan, and Lebanon said that they have an unfavorable opinion of Jews, and most have a very unfavorable view (more than $90 \%$ ). These numbers were somewhat lower in Pakistan (78\%) and Indonesia (74\%). In Indonesia, however, the negative attitudes were not as strong. "Only" $36 \%$ had very unfavorable views of Jews, and 38\% had somewhat unfavorable views. In Turkey, negative views of Jews went up from $49 \%$ in 2004 to $73 \%$ in 2009, which correlates with the rise of Erdogan, a fervent antisemitic leader of that country. In Lebanon, differences between Christians and Muslims are minimal (98\% and 97\%). By contrast, only 35\% of Muslims in Israel had a negative view of Jews, as opposed to $97 \%$ in Gaza and the West Bank (Pew Global Attitudes Project 2010).

Four years later, another survey showed that $74 \%$ of the population in Middle Eastern and North African countries agreed to at least six out of eleven antisemitic statements. Differences between the countries were large. In all Arab countries, from Morocco to Oman, at least 74\% agreed to at least six out of eleven antisemitic phrases. Antisemitic attitudes were somewhat lower in Iran (56\%) and Turkey (69\%). Numbers were even lower in Indonesia (48\%), Bangladesh (32\%), and Azerbaijan (37\%)—all predominantly Muslim countries. In some countries, there is a strong difference between the Muslim and non-Muslim populations but not in others. In Malaysia, $83 \%$ of the Muslim population and $34 \%$ of the Buddhist population believe in at least six out of eleven antisemitic statements. The difference is much smaller in India (24\% and 20\%), and there is no difference between the Christian and Muslim population in Kazakhstan (both 32\%) (Anti-Defamation League 2014). In European countries, however, surveys have shown consistently that antisemitic attitudes are significantly more widespread among the Muslim population than among the non-Muslim population (Jikeli 2015). In Germany and France, victims of antisemitism have identified Muslims as the biggest group of perpetrators (among religious, ethnic, and political groups) in different surveys (European Union Agency for Fundamental Rights 2018; Zick et al. 2017; Fourquet and Manternach 2016). Muslims in the United States are a small minority, and few surveys have focused on attitudes among Muslim Americans. A survey in the 
United States from 2017 found that while 14\% of the general American population agreed to at least six out of eleven antisemitic statements, $34 \%$ among Muslim respondents did so, which is significantly lower than their co-religionists in European countries (Anti-Defamation League 2017). However, we need to go beyond survey data to assess whether religion is an escalating factor among Muslims for a revived hatred against Jews.

Esther Webman (https://www.mdpi.com/2077-1444/10/7/415) looks at public discourses in Arab media and the instrumentalization of religion in the Arab-Israeli conflict over the last 90 years. She shows that despite the intensified exploitation of Islam in the incitement against Israel, Zionism, and the Jews, and despite the traditional enmity towards the Jews as a group deriving from Islam, the most common themes in the Arab antisemitic discourse originate from a more modern, exogenous vocabulary and perceptions. Classical Christian-Western tropes, such as conspiracy theories epitomized in the Protocols of the Elders of Zion, Nazi terminology, and Holocaust denial, are extensively used and are much more pervasive than Islamic influences.

Daniel Rickenbacher (https://www.mdpi.com/2077-1444/10/8/483) on the other hand focuses on Islamists and the Islamic State (ISIS) in particular, drawing on an analysis of one of its propaganda magazines, Dabiq. Antisemitism and the belief that Jews are at war against Islam have been central to Islamist ideology since its beginning with the Muslim Brotherhood at the end of the 1920s and Said Qutb's “Our Struggle with the Jews" (Qutb 1989, first published in or around 1950). Islamists have combined Western conspiracy theories with Islamic traditions or certain interpretations thereof. ISIS has repeatedly targeted Jews in terrorist attacks and incited hatred towards Jews in its propaganda, but it is inconsistent in its acceptance/rejection of Western-inspired antisemitic conspiracy theories. However, one of their main enemies are Shia Muslims, and ISIS claims that the Shia denomination is a Jewish invention to sow disunity among Muslims and that Shia and Jews are working together to destroy Islam.

What does that look like in South Asia, home to one-third of the global Muslim population and some of the greatest Islamic thinkers, as well as intellectual leaders of political Islam and some of the largest Islamist movements? Despite its tiny Jewish community, there were a number of extremely violent acts against Jews and Israelis in the region at the beginning of the 21st century. Navras Aafredi (https://www.mdpi.com/2077-1444/10/7/442) provides an introductory overview of antisemitism in Muslim intellectual discourses in South Asia and its historic origins. Islamic revivalism, which formed the roots of Political Islam in South Asia, were partly a response to experiences of colonialism. Today, antisemitic ideas, including Holocaust denial, are propagated in major news outlets without any objections, and popular Islamic televangelists spread antisemitic ideas. Aafredi finds three prominent themes among leading Islamists in Asia: first, Jewish antagonism against Islam since the advent of the religion; second, the depiction of racism, jealousy, stubbornness, arrogance, treason, and deceit as traits of Jewish character; and third, the accusation of the falsification of sacred texts. In India, however, antisemitism is also part of Hindu extreme right nationalism; "Jews cannot be Indian" is a widespread opinion. However, in conflict with the large Muslim minority (195 million Muslims form about $15 \%$ of the Indian population), Jews (and Israel) can be viewed sympathetically because they are perceived as enemies of Muslims. Many Indian Muslims, however, accept religious justification for why Jews should be discriminated against, for example, why Jews should not be elected for political offices if that means that they would have power over Muslims. However, is this rooted in theology or in identity politics?

So, what is the current state of affairs? Is religious antisemitism coming back? Well, at least not in its old, pre-modern forms. Both Christian white supremacists and Muslim jihadists have justified killing of Jews with a combination of conspiracy theories and theological arguments or selected sacred scripture. Christians have put old theological arguments of the New and Old Covenant into a new political context to campaign against Israel—and Jews are often affected by proxy. 
Funding: This research received no external funding.

Conflicts of Interest: The author declares no conflict of interest.

\section{References}

Améry, Jean. 1969. Der ehrbare Antisemitismus. Die Zeit, July 25.

Anti-Defamation League. 2014. “ADL GLOBAL 100". Available online: http://global100.adl.org (accessed on 2 March 2019).

Anti-Defamation League. 2017. ADL Press Release on New Poll. April 6. Available online: https://www.adl.org/ news/press-releases/in-first-new-adl-poll-finds-majority-of-americans-concerned-about-violence (accessed on 2 March 2020).

Bostom, Andrew G., ed. 2008. The Legacy of Islamic Antisemitism: From Sacred Texts to Solemn History. Reprint. New York: Prometheus Books.

European Union Agency for Fundamental Rights. 2018. Experiences and Perceptions of Antisemitism. Second Survey on Discrimination and Hate Crime against Jews in the EU. Luxembourg: European Union Agency for Fundamental Rights.

Fatah, Tarek. 2010. The Jew Is Not My Enemy: Unveiling the Myths That Fuel Muslim Anti-Semitism. Toronto: McClelland \& Stewart.

Fourquet, Jérôme, and Sylvain Manternach. 2016. L'an prochain à Jérusalem? Les Juifs de France face à l'antisémitisme. Fondation Jean-Jaurès. Paris: L'Aube, Available online: http://www.decitre.fr/livres/l-an-prochain-a-jerusalemles-juifs-de-france-face-a-1-antisemitisme-9782815913645.html (accessed on 2 March 2020).

Gallner, Marlene. 2016. Like a Cloud Contains a Storm: Jean Améry's Critique of Anti-Zionism. Fathom. Available online: http:/fathomjournal.org/like-a-cloud-contains-a-storm-jean-amerys-critique-of-antizionism/ (accessed on 2 March 2020).

Harrison, Bernard. 2013. Anti-Zionism, Antisemitism, and the Rhetorical Manipulation of Reality. In Resurgent Antisemitism: Global Perspective. Studies in Antisemitism. Edited by Alvin H. Rosenfeld. Bloomington: Indiana University Press, pp. 8-41.

Hobsbawm, Eric J. 1990. Nations and Nationalism since 1780: Programme, Myth, Reality, 2nd ed. Cambridge: Cambridge University Press.

Jikeli, Günther. 2015. Antisemitic Attitudes among Muslims in Europe: A Survey Review. ISGAP Occasional Paper Series; Edited by Charles A. Small. New York: The Institute for the Study of Global Antisemitism and Policy (ISGAP).

Lawson, Guy. 2015. Trudeau's Canada, Again. The New York Times. December 8. Available online: https: //www.nytimes.com/2015/12/13/magazine/trudeaus-canada-again.html (accessed on 2 March 2020).

Marr, Wilhelm. 1879. Der Sieg Des Judenthums Ueber Das Germanenthum. Bern: Rudolph Costenoble, Available online: https://archive.org/details/Marr-Wilhelm-Der-Sieg-des-Judenthums-ueber-das-Germanenthum-1 (accessed on 2 March 2020).

Nirenberg, David. 2013. Anti-Judaism: The Western Tradition. New York: W. W. Norton \& Co.

Ohmae, Kenichi. 1995. The End of the Nation State: The Rise of Regional Economies. New York: Simon and Schuster.

Pew Global Attitudes Project. 2010. Little Enthusiasm for Many Muslim Leaders. Available online: http: //pewglobal.org/files/pdf/268.pdf (accessed on 2 March 2020).

Qutb, Sayyid. 1989. Marakatuna Maa Al-Yahud (Our Struggle with the Jews). Cairo: Dar al-Shuruq.

Rosenfeld, Alvin H., ed. 2019. Anti-Zionism and Antisemitism: The Dynamics of Delegitimization. Bloomington: IU Press.

Sassen, Saskia. 1996. Losing Control? Sovereignty in an Age of Globalization. University Seminars/Leonard Hastings Schoff Memorial Lectures. New York: Columbia University Press.

Sekretariat der Deutschen Bischofskonferenz. n.d. Verlautbarungen des Apostolischen Stuhls 25 A Predigten und Ansprachen von Papst Johannes Paul 11. bei seinem Pastoralbesuch in Deutschland sowie Begrïßungsworte und Reden, die an den Heiligen Vater gerichtet wurden 15. bis 19. November 1980. 3. veränderte Auflage. Bonn: Verlautbarungen des Apostolischen Stuhl.

Smith, Anthony. 1995. Nations and Nationalism in a Global Era. Cambridge: Polity.

Smith, Anthony. 2000. The Nation in History: Historiographical Debates about Ethnicity and Nationalism. Oxford: Blackwell. 
Southern Poverty Law Center. 2008. Racist Black Hebrew Israelites Becoming More Militant. August. Available online: https:/www.splcenter.org/fighting-hate/intelligence-report/2008/racist-black-hebrewisraelites-becoming-more-militant (accessed on 2 March 2020).

Volkov, Shulamit. 1978. Antisemitism as a Cultural Code: Reflections on the History and Historiography of Antisemitism in Imperial Germany. The Leo Baeck Institute Year Book 23: 25-46. [CrossRef]

Wiles, Rick. 2019. Jew Coup: Seditious Jews Orchestrating Trump Impeachment Lynching. TruNews. November 23. Available online: https://www.trunews.com/podcast/jew-coup-seditious-jews-orchestrating-trumpimpeachment-lynching (accessed on 2 March 2020).

Zick, Andreas, Andreas Hövermann, Silke Jensen, and Julia Bernstein. 2017. Jüdische Perspektiven Auf Antisemitismus in Deutschland. Ein Studienbericht Für Den Expertenrat Antisemitismus Zick, Andreas; Andreas Hövermann; Silke Jensen Und Julia Bernstein. Bielefeld: Institut für interdisziplinäre Konflikt- und Gewaltforschung, Universität Bielefeld.

(C) 2020 by the author. Licensee MDPI, Basel, Switzerland. This article is an open access article distributed under the terms and conditions of the Creative Commons Attribution (CC BY) license (http://creativecommons.org/licenses/by/4.0/). 